\title{
State Policies and Their Impact on Village Governance in Colonial Era
}

\author{
${ }^{1}$ IYEP SAEFULRAHMAN, ${ }^{2}$ NENENG YANI YUNINGSIH \\ 1,2Department of Government Science, Faculty of Social and Political Science, Padjadjaran University \\ Email: ${ }^{1}$ sef73rahman@gmail.com, ${ }^{2}$ nenengyany@gmail.com
}

\begin{abstract}
Modern values applied by the Netherland / Dutch through its policies have brought changes in the people's lives of Neglasari Village in its governance back in the days. The changes were especially related to the implementation of modern bureaucracy system by forming a new power system in village government. This research aimed to analyze the implemented policies and their changes in village governance during the Dutch colonial era. Method used was qualitative research with a case study strategy. Data collection technique was focused on documentation and in-depth interview with several informants obtained through snowball technique. The research result indicates that state policies that govern the village were stated by forming a village and new modern value-based government structure. The policies did not change the previous village governance that based on local values. It was due to the leadership of the village elites that able to maintain local values in their village governance. In the end, village governance of Neglasari was based on two values, modern in its government structure but local in its governance.
\end{abstract}

Keywords: Policy, Value, Village Governance

\section{Introduction}

Village is often limited as an area occupied by a number of people with a relatively homogenous livelihood, generally in agricultural field. There is nothing wrong with the limitation since it is based on approach used. However, when considering a village from the sociological and politicsgovernmental approaches, village is basically a unit of community having the power to regulate and manage its own affairs. Through that power, the unit of community is not a general one that merely gathers but it is viewed as a self-governing community (SGC).

The power to regulate and manage owned by legal community unit is the characteristic of the existence of a village and its dynamics in Indonesia since long ago. The power is also an essential characteristic of the existence of a real democracy in the village based on its local values. The local values could be in form of local habits or customs that have become the basis in regulating the lives of its people.
As time goes by, village experiences some changes. Strong modernization is the main actor of the changes. It enters directly to the lives of the villagers as well as gives strong influence on the perspective of the government to the village. In Indonesia, changes in village government institutions are started when various interests of the state toward the village are occurred. Those interests include economy, politics, and economic-political interests.

History notes that changes in the villages (especially in Java) are started in the institutional structure of village government that occurred during kingdom era with the presence of bekel as a new authority structure of viceroy at the village of the kingdom's territories. Therefore, during the era there was an effort from the state (kingdom) to establish a state in the village. During the colonial era, village and its governance experienced changes along with the implementation of policies issued by the British colonial government in Raffles era as well as the government of Dutch East Indies.

Received: November 21, 2017, Revision: March 14, 2018, Accepted: June 04, 2018

Print ISSN: 0215-8175; Online ISSN: 2303-2499. DOI: http://dx.doi.org/10.29313/mimbar.v34i1.3221.130-137

Accredited B based on the decree No.040/P/2014, valid on February, 18, 2014 until February, 18, 2019. Indexed by DOAJ, Sinta, IPI 
In addition, affairs to be conducted by the village were increasing due to the duties and obligations assigned to the head of village, thus government structure were changing especially in terms of the roles and functions of the head of village. As it is explained by Kartohadikoesoemo (1984) that head of village is responsible for tax inclusion and the submission of the tax to the head of district (demang/wedana).

In Priangan, the strategy of colonial government was also applied. However, a village should be established as required by the state and similar to villages in Java since the legal community unit in Priangan was different to those in Java. In Priangan, the legal community unit was known as kampung instead of desa. Antlöv (2003) explanation can be a reference for the condition, which is based on the information from De Haan (1910), that the community unit called kampung was occupied by no more than 10 households of field farmers (huma or gaga). The condition was different to those villages (desa) found by the Dutch in Java, which was a group of kampung. Kampung in Java was integrated into a bigger village system. Therefore, in their initiation for intervention to the legal community unit in Priangan, the Dutch established villages (desa). One of villages where the establishment was initiated by the Dutch was Neglasari Village in the territory of Salawu,Sub-district, Tasikmalaya Regency, West Java.

The current article has no intention to describe the struggle of Neglasari in facing the state (the Dutch colonial government); however, it focused more on the analysis of the implementation of state policies that impacted the governance in Neglasari during the Dutch colonial era. It is interesting since during that era Neglasari was a legal community unit basing their governance on their own tradition. It means that modern values-based state policies were confronted with local values-based village tradition.

\section{Research Method}

The research used qualitative method since the aim of the research was to deeply analyze the implementation of state policies that regulated the village in Neglasari. In addition, it also discussed the impact of the implementation of the policies in its governance during the Dutch colonial government.
Changes occurred in Neglasari due to the impact of the implementation of state policies were not singular. Therefore, it can only be explained (and understood) using qualitative method (Sugiyono, 2005). During the research, the researcher will be faced with visible realities that might have meaning that need to be revealed, such as revealing the impact of the implementation of state policies that contain modern values which being confronted with village tradition containing local values in the governance of Neglasari village. Through qualitative research, the meaning of the revealed/visible data could be found.

In order to answer the aim of the research, this study used strategy of case study (Denzin and Lincoln, 2000). A case study will give space to specific research problems, especially specific and localscale problems such as in Neglasari Village Salawu Sub-district, Tasikmalaya Regency, West Java. A case study allows the detail in revealing specific matters. It means that the strategy allows problem exploration such as revealing anything behind the problems of political-government strategies (policies) conducted by the state that caused changes in village power as a result of government bureaucratization.

Based on research problems, data collection technique used was in-depth/ unstructured interview and documentation (Sugiyono, 2005). The techniques used to deeply reveal the implementation of state policies and their impact on governance of Neglasari Village. Informants in the research were sesepuh (the elders) of Neglasari as the listeners of history and they were selected using snowball technique. Documentation technique was chosen to strengthen and complete the historical information collected through interview. Documents can be in form of previous research results, news articles, or other writings.

Data processing and analysis used were stages as stated by Sugiyono (2005) quoting from Miles and Huberman. Activities in the data analysis were data reduction process that focuses on selection, simplification, abstraction and transformation of raw data from field record, data display process that is started with the preparation of information into statement that allow conclusion (data display), and conclusion drawing process which based on reduction and data display that take place gradually from general 
conclusion in the data reduction stage to a specific conclusion in data presentation and to a more specific in the actual conclusion drawing stage (verification).

\section{State, Policy, and Village Autonomy}

As an institution, according to Weber (in Gerth and Mills, 1974), a state has a great power and it can be used to regulate and enforce their interest. In this case, Weber sees a state as having power to do any action to its citizen. Mac Iver (1988) has similar opinion that a state has power to regulate relationships in a society by giving support or limitation in the use of power to the society. In other words, the society is in state control.

The power gives benefit to the state since they could plan and set their own direction freely. Whereas, the society, as the owner of sovereignty, is one of parties that should follow the direction set by the state. The implementation of the direction is conducted by a body or institution called government.

Government is defined as a group of people who has certain authority to conduct power through their decisions (Suryaningrat, 1990). Due to the authority that is obtained formally, the government has force power. In addition, the power of a state is legitimate due to the legitimation from whom they legally governed. Based on the scope, state's authority is not limited by certain sectors. In other words, according to Soekanto (2006), state has thorough authority.

Regarding the authority, Sanderson (1993) explains that authority is the power supported by the ability to use violence legitimately which means justification or rationalization as a moral right and it is considered as appropriate by the societies. It is related to the desire to create obedience to the government and the presence of psychological commitment to the government. According to Sanderson, the authority is a political form that is identified by Weber as a rule made upon the permission of those who are governed.

Due to the condition, it is a necessity that every element in the state obey the state decision including the government which obliged to organize the state. It can be stated that government is the real manifestation of the existence of a state. Through the government, a state could achieve and realize the direction of development and the development of the state set in a constitution.

To realize the direction aimed by the state, the government has the authority to set various decisions to perform or not perform certain action. In the conception of Dye (1978), this type of government decision is known as policy. Through the authority and legitimation, policies set by the government must be followed by the societies. In the end, it can be stated that policies become the tool of the state and government to enforce values that are believed to be true to the societies. It is in accordance with Easton's (1953) opinion stating that policy is "the authoritative allocation of values for whole society".

Policies set by the government are often aimed to support the state interests. One example is when a state set that modern values are considered better to be implemented in the society lives when in reality they already have their own power to regulate and take care of their own interest. This is the community unit that is called community legal unit or legal community unit (Kesatuan Masyarakat Hukum/KHM) by van Vallenhoven, an expert in customary law from the Netherlands. KHM, according to the study, is the development of communal community (Wignjodipoero, 1982 and Soemadiningrat, 2002). TerHaar also gave limitation related to KHM by linking it to customs that become the base of its arrangement. The community unit has fix and regular arrangement (institution). It has its administrators (leader/government) and properties that both tangible (their own potentials such as natural resources) and intangible (authority) that can be used to manage the legal unit (Wignjodipoero, 1982; Soepomo, 1996; and Soemadiningrat, 2002).

In the context of Indonesia, legal community unit has many terms depending on the circle of law where the unit is existed. As previously mentioned, the legal community unit in Java is known as desa (village), whereas in Priangan (West Java) it is known as kampung. Boeke (1971) and Kartohadikoesoemo (1984) give limitation to desa (village) as a partnership or legal unit of residence of a community that has its own power to conduct its own government. In other words, desa is a legal unit with characteristics of having its own power, territories, and properties or income. Those three characteristics are basis of village governance and originated from the customs. In political term -the government of power is 
known as autonomy defined as the authority to regulate and manage the interest of its own communities.

With the autonomy, the legal community unit has the authority to create their own rules (policies) as well as manage them (execute the rules). The authority to regulate and manage has made the unit to have the authority to select its leader and perform (organize) its government. The governance is conducted by institutions that are generally formed based on their traditions or customs. In this case, tradition or custom plays important role in the governance since it is one of important elements for an autonomous legal community unit. Ndraha (1991) places custom element as the first element that should be exist in a legal community unit. The determination of custom position indicates that custom has a significant position since it becomes the base in regulating and managing all interests of the legal community unit.

Further development indicates that power owned by the legal community unit will experience changes. In several cases, social change often leads to transformation which defined by Roy Bhaskar and quoted by Salim (2002) as a process of the creation of new thing produced by science and technology. The scope of the transformation, according to Pranaji as quoted by Munthe (2007), is not limited to changes take place on the outer form but it includes the basic form, function, structure, or characteristic of an economic activity of a society. Therefore, Munthe (2007) stated that changes occurred not only in the structure (culture and institution) but also in the process pattern.

Modernization becomes a factor that could change the life of a society as it is for legal community unit due to bureaucratization process. Theoretically, individualization, reconstruction of values and norms, the changing of future orientation, and awareness of time as part of modernization are the causes of changes as well as state policies (power) especially if the regulations in the policies contain more modern (liberal) values that empirically have incompatibility with local values (tradition and custom) owned by legal community unit. As previously explained, policies have the force power to be apt or to not necessarily be conducted by the society including when the state wants to apply modern value in governance.

Transformation occurred in a legal community unit is not always causes the power base (tradition or custom) to be faded. A process of change allows different results since it depends on the option and power of the legal community unit (the flexibility of its tradition and custom). When the legal community unit accepts (adopts) modern values offered by the state as a whole, there is a possibility that the basis of power will be faded and is replaced by values from the outside. However, if the option is to adjust then its power base will not disappear but integrate with those values from outside and create new values as its power base. In addition, if it is possible, the legal community unit will maintain its power base and work together with the values from outside. The third option has two possibilities for the legal community unit, which is conflict or harmony.

\section{The Establishment of Villages as An Initial Step of State Policy for Village Governance in Colonial Era}

Dutch arrival and the establishment of Dutch government in Indonesia (Dutch East Indies) is the milestone of change power history of legal community unit in Indonesia. The Dutch government did recognize the existence of legal community unit ( $\mathrm{KMH}$ ) to regulate its own people and customary law community unit (KMHA) that based on custom in its arrangement. The recognition was set forth in a Dutch Law article 128 Indische Staatsregering (IS) in 1854 (Boeke, 1971). However, in Priangan (West Java), the Dutch has firstly established a village. It was conducted in Priangan since the legal community unit there was not in form of desa (village) as it was in Java but a kampung, based on information from De Haan (1910) as quoted by Antlov (2003). Kampung was occupied by no more than 10 households of field farmers (huma or gaga).

The law and will of Dutch government to establish a village were considered as a policy (Dye, 1978). Policy is the real manifestation of power owned by the government to manage the country (Suryaningrat, 1990). It also indicates that a state, as stated by Weber (in Gerth and Mills, 1974) and Mac Iver (1988), does have great power in managing the direction of policies. The power owned by the state was greater, when the archipelago was under the control of the colonialist state thus the force power became stronger. Therefore, communities in the kampungs that would be combined into a village followed the will of the state only. 
In case of Neglasari village, previously known as Pasir Angin Village, the establishment was initiated by the government of Dutch East Indies by combining Kampung Pasir Angin and Sundawenang. Referring to the explanation from Kartohadikoesoemo (1984) related to the Dutch policies that combined small and less populated villages, the establishment process of Neglasari Village was closed to the truth.

By combining both kampungs, changes in power were occurred. They were initially a legal community unit (Boeke, 1971 and Kartohadikoesoemo, 1984) with the characteristics of having their own power, territories, and properties; however, when they were combined into a village, one of the kampung lost its authority. It means that the kampung was no longer had the power to regulate the interest of their own societies since they were under the power of another kampung. Fortunately, the combination of both kampungs brought no conflict between them. It was due to the communities of both kampungs who were sanaga, which is the people of kampung Naga who live outside the Kampung Naga (Saefulrahman, 2016). Therefore, the bond between them was very strong based on the custom of their ancestors who live in Kampung Naga. It is in line with Ningrum (2012) who stated that people of Kampung Naga adat is a binding power (centripetal) that could weaken the dividing external power (centrifugal).

On the other hand, Desa Pasir Angin as the result of establishment by the Dutch did not mean had more power in managing their interest. The success of the Dutch East Indies government in combining both kampungs was indirectly explained that the power of the government (state) would be more dominant than those of the village. It can be seen from the existence of loerat/lurah (head of village) and at that time it was called Lurah Curug. Referring to the information from de Klein (Antlov, 2003), the head of village replaced the existence of board of kampung. The head of village worked based on state demands, whereas board of kampung worked based on moral demands of kampung elders.

\section{The Structuring of Village Govern- ment: Second Step of State Policy in The Governance of Neglasari During- Colonial Era}

During the era of Eyang Arbasan who led the village in 1911, Pasir Angin had started to apply a structure as informed by Camareq and quoted by Antlov (2003). Although the structure was not exactly the same, the government of Pasir Angin Village, based on the research result (interview), had a clear structure in terms of the relationship lines between positions at the village. The clarity was related to the existence of role (authority) division played by the elders in the governance of Pasir Angin (in 1939 the name changed into Neglasari Village)

The existence of role division indicates that changes occurred in the power of the village. At first, village (kampung) governance was conducted "formally" by board of kampung based on moral demands only. It means that it was not based on state demands (policies) that gave duties and obligation to the structure of power of established village government, but on the self-awareness to sincerely build their own kampung. With the entry of state policies (the government of Dutch East Indies), the formal structure in the government was formed. Structure applied by the government of Dutch East Indies was surely a new thing since it used base values originated from the culture of their country.

In addition to lurah, there were also other government structures, such as the secretary of the village known as Ki Ulis. Whereas, for other structures the term used were the general ones that used in the area of law circle of West Java, such as lebe who served to help the head of the village in the enforcement of religious (Islam) affairs. There were two lebes in Desa Pasir Angin (Neglasari), namely, village lebe who administered marriage affairs and lebe cantilan who administered other religious affairs including funeral. Other structures existed during that time were village advisors who served to solve any problems occurred in the village.

Based on government structure, it can be seen that during colonial era, the arrangement of modern organization (bureaucracy) had been introduced and indicated by the existence of affairs separation. The existence of bureaucracy and affairs separation indicated that social change had occurred among the people of Pasir Angin. Durkheim statement regarding labor division with its main focus of explaining the change in society's solidarity from mechanical to organic (Morrison, 1995; Turner et.al, 1998) can be used as reference regarding the process of change occurred in 


\section{Pasir Angin Village.}

The government of Neglasari during the Dutch colonial era had been specialized with their respective roles. It means that the implementation of modern bureaucratic structure as stated by Weber (Morrison, 1995) and desired by the Dutch government had been conducted in Pasir Angin Village. The element of leader was presented in the position of lurah, staff element was conducted by the secretary of the village and the implementing element was reflected in the role of village lebe and pulisi, whereas village advisor acted as the feedback/judgment provider to the head of the village to solve problems. In addition to the three elements, there was an implementing element of region elder (another leader) reflected in the role of punduh.

In the level of practice, the established structure did not reflect the existence of head of organization and its staffs as in bureaucratic body. Leadership in the government of Pasir Angin Village was collegial in nature. It was due to the position of the leaders in the society which was as the religious figure (ajegan) and/or village elders. Therefore, lurah or the head of village was not a real leader in the bureaucracy of village government. It was similar to lebe, kulisi, and other village leaders which were not the subordinate of the head of the village.

The elders assigned as lebe, pulisi, secretary (Ki Ulis) and advisor were not appointed by the head of the village, instead they were appointed by a forum of village elders called Babadamian. The forum discussed and decided people who would be lurah and his staffs. In addition to the appointment of village officials, the forum also decided on other matters including village development. Regarding punduh, the appointment was handed over to the elders of the respective kapunuhan. Therefore, the relationship built among the elders was not in the nature of leader and those being led (superior - subordinate) but the relationship between lurah and his staffs was merely consultation and coordination. It was due to the equality between them related to their nobility and knowledge. The main element that bound them was moral demands from the village elders (especially the elders of Naga).

An interesting fact was that there was double position/function assigned to one person. However, it is important to be noted that the double position was not related to the greediness of the elders overpower or material. The double position was actually an inseparable part of the village elders. It means that, before bureaucratization (transformation of power) was conducted by the Dutch, it was common for the village elders to perform several functions as a form of moral responsibility as a villager to the village and other villagers.

The structuring of village government conducted by the Dutch government in Pasir Angin Village only managed to change the face of the village since modern bureaucracy was not reflected in governance practices of Pasir Angin. The Dutch had managed to create a new government structure in Pasir Angin (Neglasari) along with the establishment of the village. It can be stated that solidarity had changed in the community of Pasir Angin from mechanical to organic. The Dutch was the main actor in the process of change through their policies. The condition strengthens the opinion of Nordholt (1987) in his research in Java which stated that state power is the driver of social change. He saw that social change occurred due to the division of power between the state and the village that was conducted by the government. However, since the one who performed the government bureaucracy was the village elders who had their own policies and virtues based on religion and customs (due to their attachment to the Naga indigenous people), thus in exercising their power the village leaders were still in the moral demands of the village elders. It means that common morality and collective conscience, which were a set of game rules in form of norms and ethics in the society (Morrison, 1995; Turner et.al, 1998), remained a limit in the mind and action of the government of Pasir Angin Village (Neglasari). Therefore, bureaucratic system to be applied along with its division of affairs and specialization of role of each village leader (elders) did not work as expected by the Dutch East Indies. It can be seen from the existence of double position in the bureaucratic system of the village and the collegial and communal leadership style.

It seems that during the era, leaders in Pasir Angin Village met the illustration of Plato's concept of Philosopher King (Rasyd, 2000). Plato explained that for the good of a government, it is necessary that the leader is a person with the character quality of a philosopher who is full of virtue, prestige, and intelligence. One informant stated that the requirements for head of village in Pasir 
Angin (and Neglasari) were good morals, dare to speak before the people, and has dangiang or komara (identic to charisma or prestige). According to the informant, the requirements were the legacy of the village elders. According to Weber's theory of authority, leadership in Pasir Angin (Neglasari) referred to the first type, which is charismatic domination (Morrison, 2005).

\section{Village Governance Based on Two Values as The Impact of State Poli- cies Implementation in Neglasari Village}

Without deep observation, an opinion stated that the implementation of the pattern that could kill the regeneration of leadership in Neglasari is inevitable. It should be noted that at that time, the quality of characteristic of the village elders was different compared to the present leaders. Through their policies and virtues, they would know the right time to give up the leadership to the young and capable (kawasa) generation. The elders did not eager for power in the government since it was already inherent in the dangiang (charisma). It is very rare to be seen among the present leaders. This is to say that without holding any position the elders still had the power originated from their dangiang.

The power they gained at that time was indeed came from the ruler (the Dutch government) based on its structure; however, the elders in Neglasari (Pasir Angin) regarded the power due to their position as the village elders and not due to the structure or the ruler who gave them the power. Therefore, the closeness of the elders to the villagers could be maintained although they were part of the bureaucracy of the Dutch government. The closeness was stated by the present village elders who still respect and appreciate them by continuing to remember them. The term of Eyang apparently was not given during the reign of Eyang Arbasan but it was given by the next generation.

The government of Neglasari (and when it was named Pasir Angin) which was run following the bureaucracy system applied by the Dutch through the implemented policies but still stood on the local values of the village governance indicates there were two values that worked together in the government of Neglasari. The condition indicates dualistic in economic field, as stated by Boeke (1973 and 1983), also occurred in government field.
However, the two values worked together in the government did not go against each other. Both values could work together in their respective corridors. In this case, Boeke statement regarding dualism in the economy of society that could cause conflict and where modern values will gradually outdo the local values did not occur in the case of government in Neglasari.

The condition was not the strategy of the elders in Neglasari (Pasir Angin) to maintain their position. In other words, dualism in the government of Neglasari was not a strategy of adaptation of the elders. It was more due to the village elders who adhered to their common morality and collective conscience when they run the government. In their words, common morality and collective conscience referred to the philosophy of $\mathrm{Naga}$ held by the people and became their moral demands. One of the philosophies was "jaman kawulaan saur elingkeun", which mean changing times need to be followed (since it can be a supplement), but customs remain to be enforced (changes could not violate the customs of Naga).

\section{Conclusion}

State policies during colonial era to regulate the village in Neglasari were started with the establishment of a village by combining Kampung Pasir Angin and Sundawenang into Neglasari Village. After the establishment, a new government structure was formed based on modern values. In its implementation, the policy did not entirely change the village governance that previously was conducted based on the local values. The change was only in the structure, whereas the governance practice was still based on the local values. It was due to the leadership of the village elites that maintained the local values in the village governance. In the end, the governance of Neglasari village was based on two values, modern in the government structure but local in its governance.

Considering the existence of local values that still exist up to the present and have more positive impact on the characteristic of the governance in village level, it is justifiable that the government should strengthen the existence of local values in the village especially those that directly related to the governance by giving real power set forth in the policies made. Local government should conduct mapping on villages other 
than customary villages that have local tradition which implemented in regulating and managing their people interests. In addition, a compilation of customs or traditions that is maintained and prevailed in the villages in their area need to be conducted.

\section{References}

Antlöv, Hans. (2003). Negara Dalam Desa. Patronase Kepemimpinan Lokal. Yogyakarta: Lapera

Boeke, J.H. (1971). Batas-batas Dari Masyarakat Pedesaan Indonesia. Jakarta: Bhratara

Boeke, J.H. (1983). Prakapitalisme Di Asia. Jakarta: Sinar Harapan

Denzin, Norman K dan Yvonna S. Lincoln (ed) (2000). Handbook of Qualitative Research (2nd ed). Caliornia: Sage Publication, Inc.

Dye, R. Thomas. (1978). Understanding Public Policy. Prentice Hall, Inc, New Jersey

Easton, David. (1953). The Political System, New York: Knopf

Gerth, H. Harold and C. Wright Mills, eds. (1974). From Max weber: Essay in Sociology. London and Boston: Routledge and Kegan Paul Ltd.

Iver, Mac. (1988). Negara Modern. Jakarata: Aksara Baru.

Kartohadikoesoemo, Soetardjo. (1984). Desa. Jakarta: PN Balai Pustaka.

Morrison, Ken. (1995). Marx Durkheim Webber: Formations of Modern Social Thought. Great Britain: Cromwell Press Ltd.

Munthe, HM. (2007). Modernisasi dan Perubahan Sosial Masyarakat Dalam Pembangunan Pertanian: Suatu Tinjauan Sosiologis dalam Jurnal Harmoni Sosial, September 2007, Volume II, No. 1

Ndraha, Taliziduhu. (1991). Dimensi-dimensi Pemerintahan Desa. Jakarta: Bumi Aksara
Ningrum. Epon. Dinamika Masyarakat Tradisional Kampung Naga di Kabupaten Tasikmalaya. MIMBAR (Jurnal Sosial dan Pembangunan), \{S.I\}, p.47-54 Juni 2012. ISSN 2303-2499. Tersedia pada: $<$ http://ejournal.unisba.ac.id

Nordholt, Nico Schulte. (1987). Ojo Dumeh, Kepemimpinan Lokal Dalam Pembangunan. Jakarta: Pustaka Sunar Harapan.

Rasyd, Ryas. (2000). Makna Pemerintahan. Jakarta:Mutiara Sumber

Saefulrahman, Iyep. "Two Democratic Traditions in The Election of Head of Village in Neglasari, Tasimalaya. MIMBAR (Jurnal Sosial dan Pembangunan). Vol. 32, No. 2 (Desember 2016) p. 311--319. ISSN 0215-8175

Soemadiningrat, Otje Salman. (2002). Rekonseptualisasi Hukum Adat Kontemporer. Bandung: Alumni

Salim, Agus. (2002). Perubahan Sosial. Sketsa Teori dan Refleksi Metodologi Kasus Indonesia. Yogyakarta: Tiara Wacana.

Sanderson, Stephen K. (1993). Sosiologi Makro: Sebuah Pendekatan Terhadap Realitas Sosial. Farid Wajidi dan S. Menno (penerjemahj). Jakarta: Rajawali Pers

Seopomo, (1996). Bab-bab Tentang Hukum Adat (Cet. Ke-14), Jakarta: Pradnya Pramita.

Sugiyono. (2005). Memahami Penelitian Kualitatif. Bandung: Alfabeta.

Suryaningrat, Bayu. (1990). Mengenal IImu Pemerintahan (cet.2). Jakarta: Rinek Cipta

Soekanto, Soerjono. (2006). Sosiologi: Suatu Pengantar. Jakarta: Raja Grafindo Perkasa

Turner, H.J., et.all. (1998). The Emergence of Sociological Theory 4th Ed. USA: Wadsworth Publishing Comapny

Wignjodipoero, Soerojo. (1982). Pengantar dan Asas-asas Hukum Adat. Jakarta: CV Haji Masagung. 